\title{
Xylocopa sonorina Smith, 1874 from Vancouver, British Columbia, Canada (Hymenoptera: Apidae, Xylocopinae) with comments on its taxonomy
}

\author{
Cory Sheffield $d^{\ddagger}$, Jennifer Heron§, Luciana Musettil \\ ‡ Royal Saskatchewan Museum, Regina, Canada \\ $\S$ British Columbia Ministry of Environment, Species Conservation Science Unit, Vancouver, Canada \\ | The Ohio State University, Columbus, United States of America
}

Corresponding author: Cory Sheffield (cory.sheffield@gov.sk.ca)

Academic editor: Matthew Yoder

Received: 06 Jan 2020 | Accepted: 13 Apr 2020 | Published: 14 Apr 2020

Citation: Sheffield C, Heron J, Musetti L (2020) Xylocopa sonorina Smith, 1874 from Vancouver, British

Columbia, Canada (Hymenoptera: Apidae, Xylocopinae) with comments on its taxonomy. Biodiversity Data Journal 8: e49918. https://doi.org/10.3897/BDJ.8.e49918

\begin{abstract}
\section{Background}

Only one species of large carpenter bee, Xylocopa virginica (Linnaeus, 1771), has been recorded from Canada, albeit restricted to southern Ontario and Quebec. However, a single female specimen identified by Hurd in 1954 as $X$. varipuncta Patton, 1879 from British Columbia is in the C.A. Triplehorn Insect Collection at The Ohio State University (OSUC), suggesting that this species was accidentally introduced into coastal western Canada. As wood-nesters, many large carpenter bees are likely capable of expanding their range great distances by natural and unnatural transport methods while nesting inside suitable substrates, the presumed mode of transport into western Canada, and likely elsewhere. The ease at which the nests are transported has likely contributed to the nomenclatural and distributional ambiguity surrounding this species due to morphological similarities of specimens from North America, Hawaii, and several South Pacific islands.
\end{abstract}




\section{New information}

By comparing DNA barcodes of specimens from the western United States to specimens from Hawaii, we confirm the early opinion of P.H. Timberlake (Timberlake 1922) that specimens long established on the Hawaiian Islands are the same $X$. varipuncta from continental North America. Furthermore, these DNA barcode sequences also match those of specimens identified as $X$. sonorina Smith, 1874 from the French Polynesian and Samoan Islands, thus fully supporting the opinion of Groom et al. (2017) that all are likely conspecific. As $X$. sonorina, a species described from and likely introduced to Hawaii is the oldest name available, $X$. varipuncta is here placed into synonymy. Additional research will be needed to trace the timing and pathway of introduction and establishment of $X$. sonorina ; it is presumed that the species is native to the southwestern United States but has been established in Hawaii since the mid-1800s. It is also established in French Polynesia, the Samoan Islands, and likely other south Pacific islands, with additional records of occurrence from Java, New Zealand, and now Canada.

\section{Keywords}

large carpenter bees, non-native species, synonymy, DNA barcoding, distribution

\section{Introduction}

The large carpenter bees, genus Xylocopa Latreille, 1802 (Hymenoptera: Apidae, Xylocopinae), are large bumble bee sized bees that typically excavate nesting cavities into wood, bamboo, or the woody stems of plants (Hurd 1958a, Hurd 1958b, Hurd 1978a, Hurd 1978b, Gerling et al. 1989, Minckley 1998) though members of the subgenus Proxylocopa Hedicke, 1938 nest in the ground (Michener 2007). There are 32 species recorded from North America and Central America (Michener et al. 1994), many of these with recognized subspecies. Only one species has been previously recorded from Canada (Packer et al. 2007, Sheffield et al. 2017).

An interesting specimen of Xylocopa exists in the holdings of the C.A. Triplehorn Insect Collection at The Ohio State University (OSUC), a single female identified as $X$. varipuncta Patton, 1879, collected from Capilano Canyon near Vancouver, British Columbia by R.C. Osburn in 1949 (Fig. 1). The specimen was originally identified by P.H. Hurd Jr. in 1954 as Xylocopa brasilianorum varipuncta (Fig. 1d), the taxonomy likely following the classification of Ackerman (1916). Hurd (1955) later revised the genus Xylocopa occurring in California, but did not include the specimen from Canada in the distribution of $X$. brasilianorum varipuncta in that work. In later treatments (i.e., Hurd and Moure 1963) he considered $X$. varipuncta a valid species, separate from $X$. brasilianorum (Linnaeus, 1767). This unpublished Canadian record was also not included in the recent review of the subgenus Neoxylocopa Michener, 1954 (Mawdsley 2017) or in the checklist for the province of British Columbia (Sheffield and Heron 2019) due to its unlikelihood in Canada. This species is 
assumed to be native to the southwestern United States and Mexico (Hurd and Moure 1963, Mawdsley 2017).

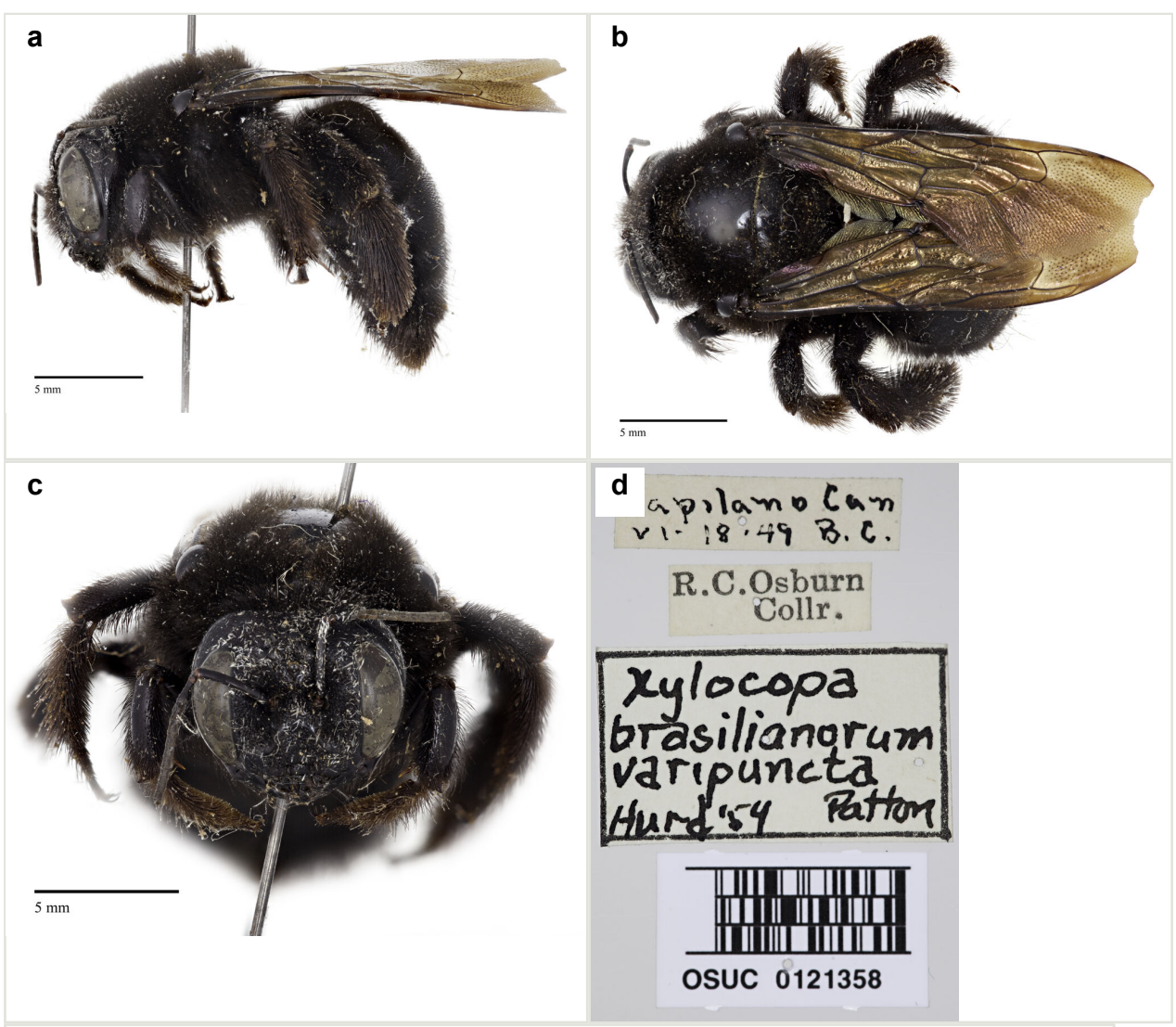

Figure 1.

Xylocopa sonorina Smith, female, from Capilano Canyon, British Columbia, Canada from Ohio State University (OSUC 0121358).
a: Lateral view doi
b: Dorsal view doi
c: Frontal view doi
d: Specimen labels doi

Here we provide images of the specimen at OSUC, confirm that it was collected in British Columbia, and review how this species, though not established in Canada, could have made it to British Columbia and to other locations by natural and/or unnatural means. We also comment on the taxonomy of this species with consideration of recent studies and analysis using molecular methods, particularly DNA barcoding, that can assist traditional taxonomic and distributional work for an increasing number of bee species, and provide an up-to-date classification with a new synonymy. 


\section{Materials and methods}

To confirm that the specimen of Xylocopa was collected in British Columbia and not a mislabeled specimen, the OSUC collection was searched for other specimens collected by R.C. Osburn from Capilano Canyon at this approximate time (i.e. in 1949). It is assumed that finding multiple specimens from the same collecting event increases the likelihood that the material was not mislabeled.

Specimens were identified using the keys of Michener (2007) to subgenus, and Mawdsley (2017) for species. To supplement existing DNA barcodes for Xylocopa in the Barcode of Life Data (BOLD) System (Ratnasingham and Hebert 2007), including sequences from GenBank accessible through BOLD, we obtained sequences from recent material collected in the continental United States (Arizona), and material collected in Hawaii held in the collection of the Royal Saskatchewan Museum (RSKM). Procedures for obtaining DNA barcode sequences follow those provided elsewhere for North American bees (Sheffield et al. 2009, Sheffield et al. 2017). Sequences of $X$. varipuncta from North America and Hawaii generated here were compared to additional sequences from these areas and from other south Pacific Islands (Groom et al. 2017) using various sequence analysis tools on BOLD, including the Taxon ID Tree and Distance Summary tools.

\section{Taxon treatment}

Xylocopa (Neoxylocopa) sonorina Smith, 1874

\section{Nomenclature}

Xylocopa sonorina Smith, 1874 in Smith 1874: 278 [이

Holotype +. HAWAII, Sandw[ich]. IsI[and]." (not Sunda Isl.; see Lieftinck (1956)) $[\mathrm{BMNH}]$ [presented by E.W.H. Holdsworth Esq to the British Museum under register 1864.8 as per Lieftinck (1956)].

Xylocopa varipuncta Patton, 1879 in Patton 1879: 60 [] [New Synonymy]

Syntypes +. USA, Arizona, by C.V. Riley [USNM]

\section{Material}

a. $\quad$ scientificName: Xylocopa sonorina Smith, 1874; kingdom: Animalia; phylum: Arthropoda; class: Insecta; order: Hymenoptera; family: Apidae; taxonRank: species; genus: Xylocopa; subgenus: Neoxylocopa; specificEpithet: sonorina; scientificNameAuthorship: Smith, 1874; continent: North America; country: Canada; stateProvince: British Columbia; locality: Capilano Canyon; verbatimLocality: Capilano Can; eventDate: 18 June 1949; verbatimEventDate: vi-18-49; sex: female; lifeStage: adult; catalogNumber: OSUC 012135; previous Identifications: Xylocopa brasilianorum varipunctata by Hurd '1954; identifiedBy: Cory S. Sheffield; dateldentified: 2019; type: PhysicalObject; institutionCode: OSUC; basisOfRecord: PreservedSpecimen 


\section{Distribution}

Presumed native to the southwestern United States and adjacent Mexico (Mawdsley 2017), and introduced to the Hawaiian Islands, French Polynesia, Samoan Islands, Java, New Zealand and likely other south Pacific islands, the Marianas Islands, and now Canada.

\section{Analysis}

We are confident that the specimen identified as $X$. varipuncta (Fig. 1) from British Columbia represents a valid record from Canada and is not mislabeled, as OSUC has several additional insect specimens collected by R.C. Osburn at Capilano Canyon from around that time (i.e., June to November 1949), including three Ichneumonidae, five specimens of Tenthredo (Symphyta, Tenthredinidae), and two specimens of Trichiosoma triangulum Kirby, 1837 (Symphyta, Cimbicidae). The latter species at least is widespread in North America, including ranging into British Columbia.

DNA barcodes from specimens of $X$. varipuncta generated in this study from western North America matched those from Hawaii, but also those from specimens in BOLD identified as $X$. sonorina Smith from the islands of Huahine-It and Mo'orea in French Polynesia, and Apia in the Samoan Islands, further supporting the opinion of Groom et al. (2017) that these are all conspecific, and confirming that this species was introduced to several Pacific Islands some time ago (i.e., Smith 1874, Cockerell 1919, Timberlake 1922). All specimens with full sequences have been assigned to Barcode Index Number (BIN; see Ratnasingham and Hebert (2013)) BOLD:ACE6828; mean genetic distance among specimens in this $\mathrm{BIN}$ is $0.52 \%$; maximum genetic distance is $0.87 \%$.

\section{Discussion}

The taxonomy of $X$. sonorina has a long and interesting history, largely impacted by its arrival and subsequent establishment in Hawaii; in fact, the type locality of this species is Hawaii (Lieftinck 1956), well outside its suspected natural range. In North America, Ackerman (1916) considered $X$. varipuncta a synonymy of $X$. brasilianorum based on morphology of females only as the male of Patton's (Patton 1879) species was unknown at that time, but considered it a distinct subspecies occurring in Arizona and southern California. Linnaeus's (Linnaeus 1767) original, albeit brief description of $X$. brasilianorum indicated the type locality "Habitat in America", but this vague geography was interpreted by Moure (2012) as probably meaning Rio de Janeiro, Brazil. Ackerman (1916) also recognized the widely distributed subspecies brasilianorum from North America (ranging from Texas, Arizona, southern California, and Mexico), south into Central and South America, and the West Indies, and also two additional subspecies, aeneipennis (De Geer, 1773) in Arizona, and cubaecola Lucas, 1857 in California. The latter two subspecies of Ackerman (1916) represent misidentifications as $X$. aeneipennis is now considered a valid species from South America (Suriname), and $X$. cubaecola is a valid species endemic to 
Cuba (Ospina 2000, Moure 2012). Hurd (1955) presumably treated these as valid species as neither was included in his key to subspecies of brasilianorum in America north of Mexico. Furthermore, Mawdsley (2017) also did not include $X$. cubaecola or $X$. brasilianorum as species of subgenus Neoxylocopa occurring in North or Central America. Timberlake (1922) felt that specimens of Xylocopa from the Hawaiian Islands (Honolulu) previously identified as $X$. aeneipennis by Smith (1879) and Blackburn and Kirby (1880) were the same as $X$. varipuncta from the continental United States, an opinion shared by T.D.A. Cockerell (as per Timberlake 1922), and later Williams (1927) and Nishida (1958); Blackburn and Kirby (1880) indicated that $X$. aeneipennis was common enough in Honolulu and elsewhere on the Hawaiian islands that it caused considerable damage to trees and timber. T.D.A. Cockerell (cited in Timberlake 1922) also felt that $X$. varipuncta was a distinct species from $X$. brasilianorum.

Though Hurd (1955) identified the specimen from British Columbia in 1954, he did not mention it or indicate a range for subspecies varipuncta extending further north than northern California; this specimen from Canada was also not mentioned by Mawdsley (2017). Hurd (1955) also indicated that material apparently identical to subspecies varipuncta had become established in Hawaii, presumably based on Timberlake (1922). Later still, Hurd and Moure (1963) recognized $X$. varipuncta as a valid species distinct from $X$. brasilianorum based on male genitalia. Hurd felt it was incorrect to call the material from Hawaii $X$. varipuncta, instead referring to it as $X$. brasilianorum sonorina Smith (Hurd 1958b; likely following Lieftinck (1956)) and $X$. sonorina (Hurd 1978a), a species originally described from the Sunda Islands, Indonesia (Smith 1874), though Lieftinck (1956) reexamined the type material and indicated that the type locality should be the Hawaiian Islands, noting a misreading of Sandw[ich]. Isl[and]. Lieftinck (1956) placed X. varipuncta (as $X$. brasilianorum varipuncta) into synonymy with $X$. b. sonorina.

The misinterpretation of the type locality for $X$. sonorina, and subsequent misidentifications of material from Hawaii has had serious implications. Though there is only one species of Xylocopa known from Hawaii (see Snelling 2003), Smith (1879) subsequently identified specimens from Honolulu (presumably the same species as his $X$. sonorina named five years previous) as $X$. aeneipennis, the species known from Suriname mentioned above. This error is likely why Timberlake (1922) also used the name $X$. aeneipennis for Hawaiian material (after Smith 1879, not De Geer 1773) and not $X$. sonorina, justifying his synonymy with the North America species $X$. varipuncta. Since Lieftinck (1956), additional authors have subsequently and correctly applied $X$. sonorina to specimens from Hawaii (e.g., Hurd 1958b, Hurd 1978a, Barrows 1980, Gerling 1982), though some have not (e.g., Tadauchi 1994). Hurd (1958b) called $X$. brasilianorum sonorina a Hawaiian carpenter bee, seeming to suggest that it was native to Hawaii, or at least non-native to the continental United States, but indicating that it had become adventive in the Marianas Islands (Krombein 1950, Tadauchi 1994) and that specimens had been also intercepted in shipments of wood in San Francisco (Hurd 1955) and Japan (Maidl 1912). Soon after, Hurd and Moure (1963) and others (e.g., Barrows 1980) did consider $X$. sororina a non-native species in the Hawaiian Islands, supporting Timberlake's (Timberlake 1922) suggestion that species in Hawaii was possibly introduced to these islands; this was also considered likely by Snelling 
(2003). Timberlake (1922), Williams (1927), Nishida (1958), and Tadauchi (1994) all felt the Hawaiian species was the same as $X$. varipuncta from the continental United States; only Linsley (1966) applied the name $X$. sonorina as an American carpenter bee.

Michener (2007) indicated that Neoxylocopa, to which this species belongs, was the only subgenus of Xylocopa occurring in both Eastern and Western Hemispheres, albeit native to the Western Hemisphere and introduced through commerce to certain Pacific Islands. It is unfortunate that Leys et al. (Leys et al. 2000, Leys et al. 2002) did not have material identified as $X$. sonorina for comparison to $X$. varipuncta in their molecular phylogenetic studies, as the recent review of this subgenus in North and Central America considered $X$. varipuncta a valid species (Mawdsley 2017), but indicated that if the species on the Hawaiian Islands turns out to be conspecific with the North American form through the use of DNA barcoding or other molecular tools, $X$. sonorina would be the correct name. Groom et al. (2017) provided such support, comparing specimens of $X$. sonorina from Samoa originally identified as $X$. varipuncta (Groom et al. 2014), French Polynesia, Hawaii, and the continental United States, though only suggested that the names may be synonymous. Additional genetic data provided here adds further support for the conspecificity of specimens from in Hawaii and North America ( $X$. varipuncta) which share DNA barcodes with specimens identified as $X$. sonorina from the islands of Huahine-It and Mo'orea in French Polynesia, and Apia in the Samoan Islands (Groom et al. 2017); X. sonorina is the oldest name available for this species, as suggested by Snelling (2003), Mawdsley (2017), and Groom et al. (2017). As such, we synonymize $X$. varipuncta under $X$. sonorina.

Following Lieftinck (1956), the Hawaiian type locality for $X$. sonorina is from an area where it was most likely introduced, but the species is likely endemic to the continental United States. Its occurrence in Hawaii and other south Pacific Islands are likely due to introductions that resulted in establishment, though other Neoxylocopa (native to the Western Hemisphere) are presumed native to the Galápagos (Cockerell 1935, Linsley 1966, Vargas et al. 2015) and Revillagigedo Islands (Hurd 1958a, Michener 2007). Xylocopa darwini Cockerell, 1926 is considered the only native bee species in the Galápagos (Hurd 1958a, Rasmussen et al. 2012, Vargas et al. 2015) and possibly first arrived in driftwood (Cockerell 1935). Hurd (1958a) suspected that X. clarionensis Hurd, 1958 of the Revillagigedo Islands was likely a recently derived form of $X$. varipuncta from the mainland, though did not speculate on how it crossed the $650 \mathrm{~km}$ to Baja California or $965 \mathrm{~km}$ to other areas of Mexico. Janzen (1964) found nests of $X$. varipuncta in a driftwood log on a beach in Mexico possibly supporting Cockerell's (Cockerell 1935) explanation for $X$. darwini; though Janzen (1964) indicated that these were likely made after the log washed ashore, it is likely for driftwood to be carried back into the ocean and transported elsewhere.

It is entirely possible that a nest with at least one specimen of $X$. sonorina arrived in coastal British Columbia within lumber via commercial means, or less likely due to the distance, within driftwood (e.g. Cockerell 1935, Linsley 1966, Vargas et al. 2015) from the United States, and subsequently emerged and was captured. Short travel times of driftwood logs in ocean currents may promote short distance dispersal in wood-nesting bees, but would likely not support the long distance travel and survival from North America to the Hawaiian 
Islands, French Polynesia, and the Samoan Islands. However, the hypothesized $<1,000$ $\mathrm{km}$ explanations for the natural arrival of $X$. darwini to the Galápagos, and $X$. clarionensis to the Revillagigedo Islands could be possible (Hurd 1958a). In ocean currents, some driftwood is capable of travelling great distances (e.g., Eggertsson 1993) provided it does not lose buoyancy, which typically can occur with 6 months to 1.5 years (Häggblom 1982), with logs of lesser volume (Eggertsson 1993) or greater density (Ruiz-Villanueva et al. 2014) with decreased buoyancy. For many animals, total travel time is likely the main issue for successful natural dispersal in oceans over great distances (see de Queiroz 2014). However, no species of Xylocopa is yet known to have multiyear diapause that would facilitate extensive long distance/time travel in wood; all such species winter as prepupae while members of the subfamily Xylocopinae typically overwinter in adult groups containing both males and females (reviewed by Danforth et al. 2019). Michener (Michener 1979, Michener 2007) indicated that few bee species are likely capable of natural long distance dispersal by flight, typically favouring larger species (e.g., Araújo et al. 2004, Greenleaf et al. 2007), partially explaining why most oceanic islands are naturally depauperate of apoid species. Longer distance dispersal by bees is more likely facilitated by nest transport, thus favouring species like carpenter bees that nest in wood or other movable substrates (Michener 1979), and smaller bees, such as Hylaeus Fabricius, 1793 (Colletidae) are probably more suitable for long distance travel than larger bees (Michener 1979, Daly and Magnacca 2003).

Much faster travel time of materials containing bee nests is obtained via commerce, which is likely the main means of introduction today. Recently, a carpenter native to Japan and China was found in California (Dahlberg et al. 2013), suggesting that commerce is likely important. There are also historic records of other native North American species of Xylocopa being intercepted at other locations; Hurd (1961) (citing Dover 1924) indicated that $X$. virginica was collected in Nottingham England from nests built in wood. Groom et al. (2017) suggest that early Polynesian seafarers could have transported wood containing nests to several islands at a rate that would promote establishment, but also suggested that more recent and purposeful introduction of this species for passionfruit pollination may have occurred. However, this species was introduced on several Pacific Islands some time ago (i.e., Smith 1874, Cockerell 1919, Timberlake 1922), though this species was not recorded in any of the South Pacific regions covered by Michener (1965). Incidentally, nests of smaller bee species would also be harder to detect in materials inspecition at international borders; in Canada, at least 20 species of wood- or stem-nesting bees, most of them small, have been introduced and established (see Sheffield et al. 2011, Gibbs and Dathe 2017, Martins et al. 2017, Normandin et al. 2017). Other larger species (i.e., Megachile xylocopoides Smith, 1853 (Megachilidae)) have been intercepted at the Canadian border, but have not been recorded as established (Sheffield et al. 2011).

Once arriving to a new location, some bee species can succeed even with very low numbers of colonizers. Zayed et al. (2007) showed that some bee species may be able to successfully establish and become widespread with very few individuals introduced to a new area, possibly even a single mated female. Though a single female of $X$. sonorina is now known from British Columbia, no subsequent work has confirmed its establishment in 
Canada (see Sheffield and Heron 2019). Considering the nesting and wintering biology described for this species by Giffard (1922), Williams (1927) and Gerling (1982) [material from Hawaii], it is possible that several individuals were transported from the continental United States to these Pacific Islands, or perhaps it island-hopped from an initial establishment event in Hawaii, where the species has occurred since at least the mid-1870s (Smith 1874). Interestingly, this species also seems to have made it as far west as Java in Indonesia (Cockerell 1919) and more recently, on at least two occasions, New Zealand (Donovan 1988, Manson 1988). Donovan (2007) indicated that only males were found in the nests found in New Zealand, and suggested this was likely due to the egg laying female not being mated pre-arrival, suggesting that perhaps an unmated female and not an established or wintering nests of contain both males and females arrived. Thus, the reproductive status of immigrant populations, and the ability to take advantage of new habitat likely influence successful establishment of bees around the globe.

\section{References}

- $\quad$ Ackerman AJ (1916) The carpenter-bees of the United States of the genus Xylocopa . Journal of the New York Entomological Society 24: 196-232. URL: https://www.jstor.org/ stable/25003718

- $\quad$ Araújo ED, Costa M, Chaud-Netto J, Fowler HG (2004) Body size and flight distance in stingless bees (Hymenoptera: Meliponini): inference of flight range and possible ecological implications. Brazilian Journal of Biology 64: 563-568. https://doi.org/ 10.1590/s1519-69842004000400003

- $\quad$ Barrows EM (1980) Robbing of exotic plants by introduced carpenter and honey bees in Hawaii, with comparative notes. Biotropica 12 (1): 23-29. https://doi.org/

\section{$10.2307 / 2387770$}

- $\quad$ Blackburn T, Kirby WF (1880) Notes on species of aculeate Hymenoptera occurring in the Hawaiian Islands. The Entomologist's Monthly Magazine 17: 85-89.

- Cockerell TDA (1919) Bees in the collection of the United States National Museum.-3. Proceedings of the United States National Museum 55: 167-221. https://doi.org/ 10.5479/si.00963801.55-2264.167

- Cockerell TDA (1935) The carpenter bees of the Galapagos Islands. Proceedings of the California Academy of Sciences, 4th Series 21: 379-382.

- $\quad$ Dahlberg L, Hauser M, Yanega D (2013) Japanese carpenter bee, Xylocopa appendiculata Smith 1852 (Hymenoptera: Apidae) potentially established in Santa Clara County, first record for North America. The Pan-Pacific Entomologist 89 (4): 226-229. https://doi.org/10.3956/2013-22.1

- Daly HV, Magnacca KN (2003) Hawaiian Hylaeus (Nesoprosopis) bees. Insects of Hawaii 17: 1-234. URL: http://hdl.handle.net/10125/32718

- Danforth BN, Minckley RL, Neff JL (2019) The Solitary Bees. Princeton University Press, Princeton. https://doi.org/10.2307/j.ctvd1c929

- De Geer C (1773) Mémoires pour server à l'histoire des insectes. 3. Imprimerie Royale, Paris, $696 \mathrm{pp}$.

- de Queiroz A (2014) The Monkey's Voyage: How Improbable Journeys Shaped the History of Life. Basic Books, New York, 368 pp. [ISBN 978-0-465-02051-5] 
- Donovan BJ (1988) Occurrence of Xylocopa sonorina Smith in New Zealand. Melissa 3: 21.

- Donovan BJ (2007) Apoidea (Insecta: Hymenoptera). Fauna of New Zealand 57: 1-295.

- Dover C (1924) Some observations on the bionomics of Xylocopa aestuans Linn. (Apidae). Transactions of the Royal Entomological Society of London 72 (1-2): 144-150. https://doi.org/10.1111/j.1365-2311.1924.tb03354.x

- $\quad$ Eggertsson Ó (1993) Origin of the driftwood on the coasts of Iceland; a dendrochronological study. Jökull 43: 15-32.

- Gerling D (1982) Nesting biology and flower relationships of Xylocopa sonorina Smith in Hawaii (Hymenoptera: Anthophoridae). The Pan-Pacific Entomologist 58 (4): 336-351.

- Gerling D, Velthuis HHW, Hefetz A (1989) Bionomics of the large carpenter bees of the genus Xylocopa . Annual Review of Entomology 34: 163-190. https://doi.org/10.1146/ annurev.en.34.010189.001115

- Gibbs J, Dathe HH (2017) First records of Hylaeus (Paraprosopis) pictipes Nylander, 1852 (Hymenoptera: Colletidae) in North America. Check List 13 (3): 1-6. https://doi.org/ 10.15560/13.3.2116

- $\quad$ Giffard WM (1922) Observations on Xylocopa and Lithurgus (Hymenoptera). Proceedings of the Hawaiian Entomological Society 5: 53-54.

- Greenleaf SS, Williams NM, Winfree R, Kremen C (2007) Bee foraging ranges and their relationship to body size. Oecologia 153: 589-596. https://doi.org/10.1007/ s00442-007-0752-9

- $\quad$ Groom SVC, Ngo HT, Rehan SM, Skelton P, Stevens MI, Schwarz MP (2014) Multiple recent introductions of apid bees into Pacific archipelagos signify potentially large consequences for both agriculture and indigenous ecosystems. Biological Invasions 16 : 2293-2302. https://doi.org/10.1007/s10530-014-0664-7

- Groom SVC, Stevens MI, Ramage T, Schwarz MP (2017) Origins and implications of apid bees (Hymentopera: Apidae) in French Polynesia. Entomological Science 20 (1): 65-75. https://doi.org/10.1111/ens. 12230

- Häggblom A (1982) Driftwood in Svalbard as an indicator of sea ice conditions. Geografiska Annaler 64A: 81-94. https://doi.org/10.2307/520496

- Hurd PD (1955) The carpenter bees of California. Bulletin of the California Insect Survey 4: 35-72.

- Hurd PD (1958a) The carpenter bees of the eastern Pacific oceanic islands (Hymenoptera: Apoidea). Journal of the Kansas Entomological Society 31 (4): 249-255.

- Hurd PD (1958b) Observations on the nesting habits of some New World carpenter bees with remarks on their importance in the problem of species formation (Hymenoptera: Apoidea). Annals of the Entomological Society of America 51 (4): 365-375. https://doi.org/10.1093/aesa/51.4.365

- Hurd PD (1961) A synopsis of the carpenter bees belonging to the subgenus Xylocopoides Michener (Hymenoptera; Apoidea). Transactions of the American Entomological Society 87 (4): 247-257. URL: http://www.jstor.org/stable/25077825

- Hurd PD, Moure JS (1963) A classification of the large carpenter bees (Xylocopini) (Hymenoptera: Apoidea). University of California Publications in Entomology 29: 1-365. Hurd PD (1978a) An annotated catalog of the carpenter bees (genus Xylocopa Latr.) of the Western Hemisphere (Hymenoptera, Anthophoridae). Smithsonian Institution Press, Washington, $116 \mathrm{pp}$. 
- Hurd PD (1978b) Bamboo-nesting carpenter bees (genus Xylocopa Latreille) of the subgenus Stenoxylocopa Hurd and Moure. Journal of the Kansas Entomological Society 51 (4): 746-764.

- Janzen DH (1964) Xylocopa (Neoxylocopa) varipuncta nesting in driftwood in Mexico. The Pan-Pacific Entomologist 40 (1): 65-66.

- Krombein KV (1950) The aculeate Hymenoptera of Micronesia. II. Colletidae, Halictidae, Megachilidae, and Apidae . Proceedings of the Hawaiian Entomological Society 14 (1): 101-142. URL: http://hdl.handle.net/10125/16216

- Leys R, Cooper SJB, Schwarz MP (2000) ) Molecular phylogeny of the large carpenter bees, genus Xylocopa (Hymenoptera: Apidae), based on mitochondrial DNA sequences. Molecular Phylogenetics and Evolution 17 (3): 407-418. https://doi.org/ 10.1006/mpev.2000.0851

- $\quad$ Leys R, Cooper SJB, Schwarz MP (2002) Molecular phylogeny and historical biogeography of the large carpenter bees, genus Xylocopa (Hymenoptera: Apidae). Biological Journal of the Linnean Society 77 (2): 249-266. https://doi.org/10.1046/j. 1095-8312.2002.00108.x

- Lieftinck MA (1956) Revision of the carpenter bees (Xylocopa Latreille) of the Moluccan Islands, with notes on other Indo-Australian species. Tijdschrift voor Entomologie 99: 55-73.

- Linnaeus C (1767) Systema naturæ per regna tria naturæ, secundum classes, ordines, genera, species, cum characteribus \& differentiis. 2. Holmiæ (Salvius), Stockholm.

- $\quad$ Linsley EG (1966) Pollinating insects of the Galápagos Islands. In: Bowman RI (Ed.) The Galápagos. Proceedings of the Symposia of the Galápagos International Scientific Project. University of California Press, Berkeley, $318 \mathrm{pp}$.

- Maidl F (1912) Die Xylocopen (Holzbienen) des Wiener Hofmuseums. Ein Beitrag zu einter Monographie dieser Gattung. Annalen des Naturhistorischen Museums in Wien 26 (3/4): 249-330.

- Manson DCM (1988) The occurrence of the carpenter bee, Xylocopa sonorina in New Zealand. Weta 11 (1): 4-5.

- Martins KT, Normandin É, Ascher JS (2017) Hylaeus communis (Hymenoptera: Colletidae), a new exotic bee for North America with generalist foraging and habitat preferences. The Canadian Entomologist 149 (3): 377-390. https://doi.org/10.4039/tce. 2016.62

- $\quad$ Mawdsley J (2017) Large carpenter bees: A guide to species of Xylocopa (Neoxylocopa) from North and Central America. Pineway Press, University Park, 68 pp. [ISBN 978-1981740970]

- Michener CD (1965) A classification of the bees of the Australian and South Pacific regions. Bulletin of the American Museum of Natural History 130: 1-362.

- Michener CD (1979) Biogeography of the bees. Annals of the Missouri Botanical Garden 66 (3): 277-347. https://doi.org/10.2307/2398833

- Michener CD, McGinley RJ, Danforth BN (1994) The bee genera of North and Central America (Hymenoptera: Apoidea). Smithsonian Institution Press, Washington, 209 pp. [ISBN 156098256X]

- Michener CD (2007) The Bees of the World. 2. Johns Hopkins University Press, Baltimore, 953 pp. [ISBN 0801885736] 
- Minckley RL (1998) A cladistics analysis and classification of the subgenera and genera of the large carpenter bees, tribe Xylocopini (Hymenoptera: Apidae). Natural History Museum, The University of Kansas Scientific Papers 9: 1-47.

- Moure JS (2012) Xylocopini Latreille, 1802. In Moure JS, Urban D, Melo GAR (Orgs). Catalogue of Bees (Hymenoptera, Apoidea) in the Neotropical Region - online version. http://www.moure.cria.org.br/catalogue. Accessed on: 2019-11-06.

- $\quad$ Nishida T (1958) Pollination of the passion fruit in Hawaii. Journal of Economic Entomology 51 (2): 146-149. https://doi.org/10.1093/jee/51.2.146

- Normandin É, Vereecken NJ, Buddle CM, Fournier V (2017) Taxonomic and functional trait diversity of wild bees in different urban settings. PeerJ 5 https://doi.org/10.7717/ peerj.3051

- Ospina M (2000) Abejas Carpinteras (Hymenoptera: Apidae: Xylocopinae: Xylocopini) de la Región Neotropical. Biota Colombiana 1 (3): 239-252.

- Packer L, Genaro JA, Sheffield CS (2007) The bee genera of Eastern Canada. Canadian. Journal of Arthropod Identification 3 URL: http://www.biology.ualberta.ca/bsc/ ejournal/pgs03/pgs 03.html

- $\quad$ Patton WH (1879) Notes on three species Xylocopa . The Canadian Entomologist 11 (3): 60. https://doi.org/10.4039/Ent1160-3

- Rasmussen C, Carríon AL, Castro-Urgal R, Chamorro S, Gonzalez VH, Griswold TL, Herrera HW, McMullen CK, Olesen JM, Traveset A (2012) Megachile timberlakei Cockerell (Hymenoptera: Megachilidae): Yet another adventive bee species to the Galápagos Archipelago. The Pan-Pacific Entomologist 88 (1): 98-102. https://doi.org/ 10.3956/2012-04.1

- Ratnasingham S, Hebert PDN (2007) BOLD: The Barcode of Life Data System (http:// www.barcodinglife.org). Molecular Ecology Notes 7 (3): 355-364. https://doi.org/10.1111/ j.1471-8286.2007.01678.x

- Ratnasingham S, Hebert PDN (2013) A DNA-based registry for all animal species: The Barcode Index Number (BIN) System. PLOS One 8 (7). https://doi.org/10.1371/ journal.pone.0066213

- Ruiz-Villanueva V, Stoffel M, Piégay H, Gaertner V, Perret F (2014) Wood density assessment to improve understanding of large wood buoyancy in rivers. In: Schleiss $A$, De Cesare G, Franca M, Pfister M (Eds) River Flow 2014: Proceedings of the International Conference on Fluvial Hydraulics (River Flow 2014), Lausanne, Switzerland, 3-5 September 2014. CRC Press, Leiden. [ISBN 9780429069246]. https:// doi.org/10.1201/b17133-333

- Sheffield CS, Hebert PDN, Kevan PG, Packer L (2009) DNA barcoding a regional bee (Hymenoptera: Apoidea) fauna and its potential for ecological studies. Molecular Ecology Resources 9: 196-207. https://doi.org/10.1111/j.1755-0998.2009.02645.x

- $\quad$ Sheffield CS, Dumesh S, Cheryomina M (2011) Hylaeus punctatus (Hymenoptera: Colletidae), a bee species new to Canada, with notes on other non-native species. Journal of the Entomological Society of Ontario 142: 29-43.

- Sheffield CS, Heron J, Gibbs J, Onuferko TM, Oram R, Best L, deSilva N, Dumesh S, Pindar A, Rowe G (2017) Contribution of DNA barcoding to the study of the bees (Hymenoptera: Apoidea) of Canada: progress to date. The Canadian Entomologist 149 (6): 736-754. https://doi.org/10.4039/tce.2017.49

- Sheffield CS, Heron JM (2019) The bees of British Columbia (Hymenoptera: Apoidea, Apiformes). Journal of the Entomological Society of British Columbia 115: 44-85. 
- Smith F (1874) X. Monograph of the genus Xylocopa Latr. Transactions of the Entomological Society of London 21 (2): 181-206. https://doi.org/10.1111/j.

1365-2311.1874.tb00168.x

- Smith F (1879) Descriptions of new Species of Aculeate Hymenoptera collected by the Rev. Thos. Blackburn in the Sandwich Islands. Journal of the Linnean Society of London, Zoology 14 (79): 674-685. https://doi.org/10.1111/j.1096-3642.1879.tb02459.x

- $\quad$ Snelling RR (2003) Bees of the Hawaiian Islands, exclusive of Hylaeus (Nesoprosopis) (Hymenoptera: Apoidea). Journal of the Kansas Entomological Society 76 (3): 342-356.

- Tadauchi O (1994) Bees of the Mariana Islands, Micronesia, collected by the Expedition of the Natural History Museum \& Institute, Chi ba (Hymenoptera, Apoidea). Esakia 34: 215-225.

- Timberlake PH (1922) Identify of the Hawaiian carpenter bee of the genus Xylocopa (Hymenoptera). Proceedings of the Hawaiian Entomological Society 5: 51.

- Vargas P, Rumeu B, Heleno RH, Traveset A, Nogales M (2015) Historical isolation of the Galápagos Carpenter Bee (Xylocopa darwini) despite strong flight capability and ecological amplitude. PLOS One 10 (3). https://doi.org/10.1371/journal.pone.0120597

- Williams FX (1927) Notes on the habits of the bees and wasps of the Hawaiian Islands. Proceedings of the Hawaiian Entomological Society 6 (3): 425-464.

- Zayed A, Constantin ŞA, Packer L (2007) Successful biological invasion despite a severe genetic load. PLOS One 2 (9). https://doi.org/10.1371/journal.pone.0000868 